\title{
An investigation on marketing mix efforts on brand equity: An empirical investigation in mobile phone industry
}

\author{
Nasr Azad $^{\mathrm{a}^{*}}$, Ozhan Karimi ${ }^{\mathrm{b}}$ and Maryam Safaei ${ }^{\mathrm{b}}$
}

${ }^{a}$ Department of Management, Islamic Azad University, South Tehran Branch, Tehran, Iran

${ }^{b}$ Department of Management, Payame Noor University, Tehran, Iran

ART I CLEINFO ABSTRACT

Article history:

Received December 1, 2011

Received in Revised form

February, 14, 2011

Accepted 20 March 2012

Available online

March 262012

Keywords:

Perception quality

Word of mouth advertisement

Brand image

Mobile industry

\section{Introduction}

Brand is one of the most important intangible assets in today's enterprises and in many cases; an enterprise is mostly valued mainly based on its brand. During the past few two decades, there have been numerous efforts to measure the impact of brand on customer's purchasing intention (Lee \& Back, 2011).

Yoo and Donthu (2001) presented the results of a multistep investigation to develop a multidimensional consumer-based brand equity scale (MBE). They used a sample of 1530 American, Korean American, and Korean people and assessed 12 brands from three product categories including athletic shoes, film for cameras, and color television sets. Their results showed that the new brand

\footnotetext{
* Corresponding author. Tel. + 982122895719

E-mail addresses: dr.naserazad@yahoo.com (N. Azad)

(c) 2012 Growing Science Ltd. All rights reserved. doi: $10.5267 /$ j.msl.2012.03.018 
equity scale is reliable, valid, parsimonious, and could be used across various cultures and product categories.

Baldauf et al. (2009) studied the effects of product-country image (PCI) on retailer-perceived brand equity and ultimate brand profitability performance and reported that both marketing activities and PCI influence retailer-perceived brand equity with PCI also strongly and positively could impact brand profitability performance. Bendixen et al. (2004) explained the concept of brand equity in a special industrial marketing setting by investigating the sources of brand equity. They also studied the appropriate communications strategy and the relative importance of brand relative to other purchase criteria. The research strategy implemented was a conjoint analysis study. The results indicated that while brand equity played an important role, price and delivery were more important. However, a price premium can be achieved when a firm has high brand equity.

Boo et al. (2009) investigated a destination brand model by using customer-based brand equity models through a scale purification study. The proposed study and the alternative framework were examined with an online survey sample of Las Vegas and Atlantic City visitors. The results confirmed the concept of customer-based brand equity and corroborated its application to the destination context.

There are extensive studies dedicated on brand equity primarily from a consumer viewpoint, but there are not much work on retailer's point of view. Retailers are the actual participants in the value chain who sell their products to consumers and they are able to impact consumers' evaluations and buying decisions, substantially. Baldauf et al. (2009) investigated the effects of retailer-perceived brand equity and ultimate brand profitability performance and marketing activities on brand equity. They reported that both marketing activities and PCI influence retailer-perceived brand equity with PCI positively influencing brand profitability performance.

Bandyopadhyay and Martell (2007) presented an especial method to measure attitudinal loyalty. They performed an empirical survey data with a relatively large sample of 1800 respondents, which incorporated both purchase patterns and attitudes of the respondents for all major brands of toothpaste, to show that behavioral loyalty could be influenced by attitudinal loyalty across various brands of the toothpaste group. Burmann et al. (2009) presented an integrated brand equity method by exploring the sources of brand equity at the behavioral and financial levels to reach a more comprehensive and sustainable brand equity measurement method.

Netemeyer et al. (2004) demonstrated the results of four studies, which developed measures of “core/primary"' facets of customer-based brand equity (CBBE). The methods are based on CBBE structures and the figures selected were perceived quality (PQ), perceived value for the cost (PVC), uniqueness, and people's attraction to pay a price premium for a brand. Their results explained that PQ, PVC, and brand uniqueness are potential direct antecedents of the price premium payment for a brand. Kohli et al. (2005) reported the results of a study of evaluation of new brand names and demonstrated that meaningful brand names continue to be evaluated more favorably than nonmeaningful names.

Homburg et al. (2010) described that in business-to-business (B2B) environments, many service providers concentrate their branding activities on brand name and logo without working on brand identity. As a result, the creation of brand awareness plays an essential impact in various B2B branding strategies. They reported the results of their study from a cross-industry study of more than 300 B2B firms indicated that brand awareness influences market performance.

Joon-Wuk Kwun and Oh (2007) showed how consumers could evaluate lodging brand portfolios and described the relative importance of brand-specific associations and brand portfolio factors in forming brand behaviors toward extended brands. They explained that brand-specific associations and brand portfolio impact consumers' evaluations of extended brands. In addition, brand fit and 
familiarity in their study played an important role in consumers' behavior formation because they moderated behavior transferability between a brand portfolio and its extended brands.

Kim et al. (2008) reported five important factors, which influence the creation of brand equity through successful implementation of CRM including trust, customer satisfaction, relationship commitment, brand loyalty, and brand awareness. The investigation of the relationships among these factors recommended that many hospitals could be more successful in creating image and positive brand equity if they could manage their customer relationships well.

Lee and Back (2008) studied CHRIE conference attendee behaviors from the perspective of brand equity using structural equation analyses and reported that professional education, staff service, site selection, and social networking were positively associated with brand satisfaction, whereas brand awareness was negatively related with it.

Pappu and Quester (2006) investigated on consumer-based method for retailer equity measurement and described some of the limitations associated with current retailer equity measurement such as a lack of clarity relating its nature and dimensionality and conceptualized retailer equity as a fourdimensional construct comprising retailer awareness, retailer associations, perceived retailer quality, and retailer loyalty. The brand names also influenced evaluations of quality and other product attributes. Sweeney and Swait (2008) investigated the influences of brand credibility on customer loyalty by investigating the relative importance of the brand in managing the churn of current customers of relational services and indicated that brand credibility serves in a defensive role and it substantially enhances word-of-mouth and reduces switching behaviors among customers. Huang and Sarigöllü (2011) investigated on how brand awareness is associated with market outcome, brand equity, and the marketing mix.

The study of this paper attempts to study an investigation on marketing mix efforts on brand equity. The organization of this paper first presents details of survey in section 2. Section 3 explains the findings of the survey and concluding remarks are given in the last to summarize the contribution of this paper.

\section{Proposed study}

The proposed study of this paper uses a questionnaire consists of 26 questions and distributes it among 428 people who are randomly chosen from the people who live in Tehran, the capital city of Iran. Cronbach Alpha (1951) has been calculated as 0.9, which well above the minimum desirable level. About $56.3 \%$ of the participants were female and the remaining $43.7 \%$ were man. In addition, $57.0 \%$ of the participants were single and the remaining $43.0 \%$ were married. $17.3 \%$ of the participants were 20 years or younger, $62.1 \%$ of the participants aged between 21 to 30 years, $12.6 \%$ between 31 to 40, 5.6\% were between 41 to 50 and only $2.3 \%$ were older than 50 . Table 1 shows people's educational background, income and brand name they use.

\section{Table 1}

Educational background, Income and brand name

\begin{tabular}{|c|c|c|c|c|c|}
\hline Years of education & $<12$ & 12 & 14 & 16 & $>16$ \\
\hline Percentage & 7.5 & 14.5 & 9.3 & 50.9 & 17.8 \\
\hline Income & $<300$ US\$ & \multicolumn{3}{|c|}{ Between 300US\$ and 600US\$ } & $>600$ US\$ \\
\hline Percentage & 53.7 & \multicolumn{3}{|c|}{36.0} & 10.3 \\
\hline Brand name & Nokia & Sony & Samsung & Others & \\
\hline Percentage & 45.8 & 32.7 & 15.7 & 6.1 & \\
\hline
\end{tabular}

Table 2 shows details of all questions 
Table 2

Statistical results

\begin{tabular}{|c|c|}
\hline \multicolumn{2}{|l|}{ Q. } \\
\hline & Loyalty \\
\hline 1 & I am loyal to this brand. \\
\hline 2 & This is my priority purchasing brand. \\
\hline \multirow[t]{2}{*}{3} & I choose this brand even if there are other options. \\
\hline & Quality perception \\
\hline 4 & This brand maintains high quality products \\
\hline \multirow[t]{2}{*}{5} & This brand has high performance. \\
\hline & Awareness \\
\hline 6 & I have enough information about this brand. \\
\hline 7 & Among all existing brands, I remember this brand more easily. \\
\hline \multirow[t]{2}{*}{8} & As soon as I hear this brand, I remember its logo. \\
\hline & Exclusiveness \\
\hline 9 & This brand has exclusive characteristics compared with other brands. \\
\hline \multirow[t]{2}{*}{10} & This brand has different characteristics compared with other brands. \\
\hline & Word of mouth advertisement \\
\hline 11 & I recommend this brand to others. \\
\hline \multirow[t]{2}{*}{12} & I will deliver my good experience on this brand to others. \\
\hline & Brand name image \\
\hline 13 & This band maintains products with beautiful image. \\
\hline 14 & The people who use this brand are attractive. \\
\hline \multirow[t]{2}{*}{15} & The brand preserves modern features. \\
\hline & Advertisement \\
\hline 16 & I chose this brand based on advertisement. \\
\hline 17 & Massive advertisement shows strong brand. \\
\hline 18 & What we see from advertisement is very clear. \\
\hline \multirow[t]{2}{*}{19} & This brand represents better quality products compared with other brands. \\
\hline & 要 \\
\hline 20 & Price is an important parameter on choosing this brand. \\
\hline \multirow[t]{2}{*}{21} & This brand preserves better quality compared with its price. \\
\hline & Distribution \\
\hline 22 & It is straightforward to purchase this brand. \\
\hline \multirow[t]{2}{*}{23} & This brand can be accessed from anywhere. \\
\hline & Guarantee \\
\hline 24 & This brand follows continuous improvement. \\
\hline 25 & We can highly trust this brand. \\
\hline 26 & This brand maintains high quality products. \\
\hline
\end{tabular}

\section{Results}

In this section, we present details of the finding on the implementation of the proposed study. In our study, we have used LISREL software package to analyze the questions, which were gathered using Likert scale (Likert, 1932). Table 2 shows details of our finding along with the questions. The results of the implementation of LISREL software packages are GFI= 0.96, AGFI $=0.91, \mathrm{NFI}=0.94$, $\mathrm{NNFI}=0.95$, which are well above the desirable value. 


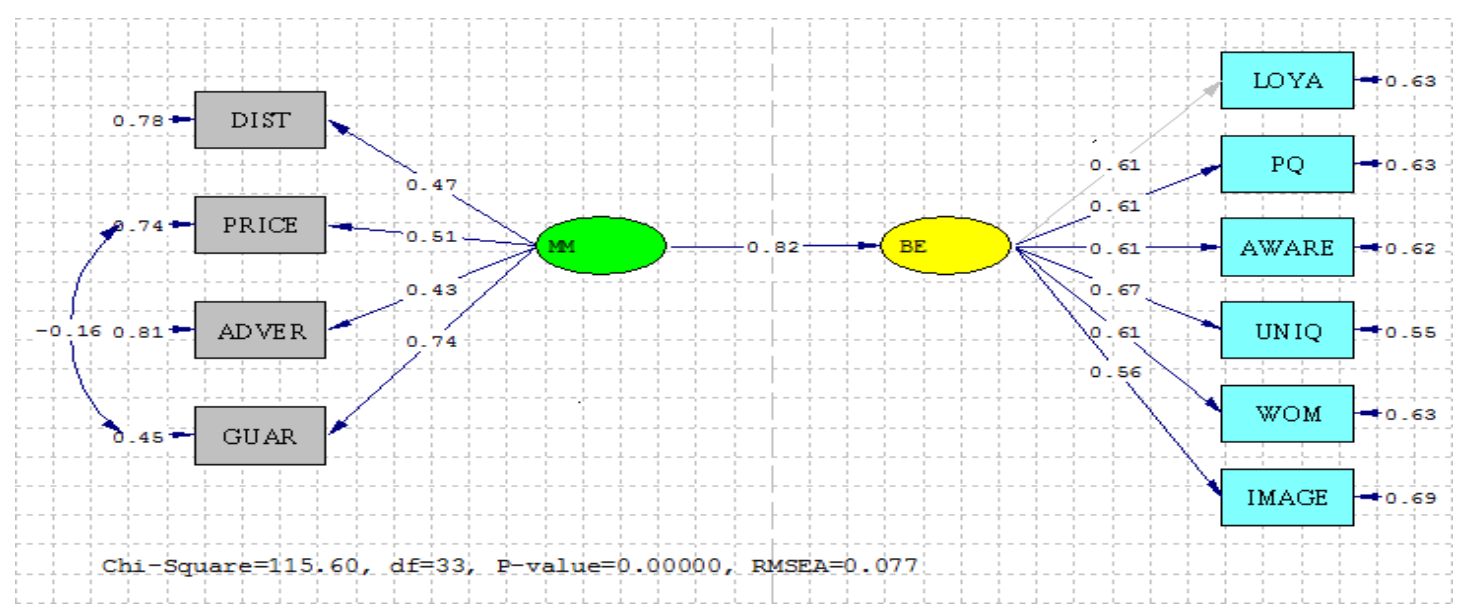

Fig. 1. Structural modeling framework

In Fig. 1, LOYA is associated with loyalty, PQ represents perception quality, AWARE is the awareness, UNIQ is the uniqueness of the product, WOM is the word of mouth, IMAGE is also presents the image. In the proposed model, BE represents brand equity, DIST, PRICE, ADVER and GUAR are distribution services, price, advertisement, and the characteristics of guarantee, respectively. Fig. 2 shows details of our proposed standard model.

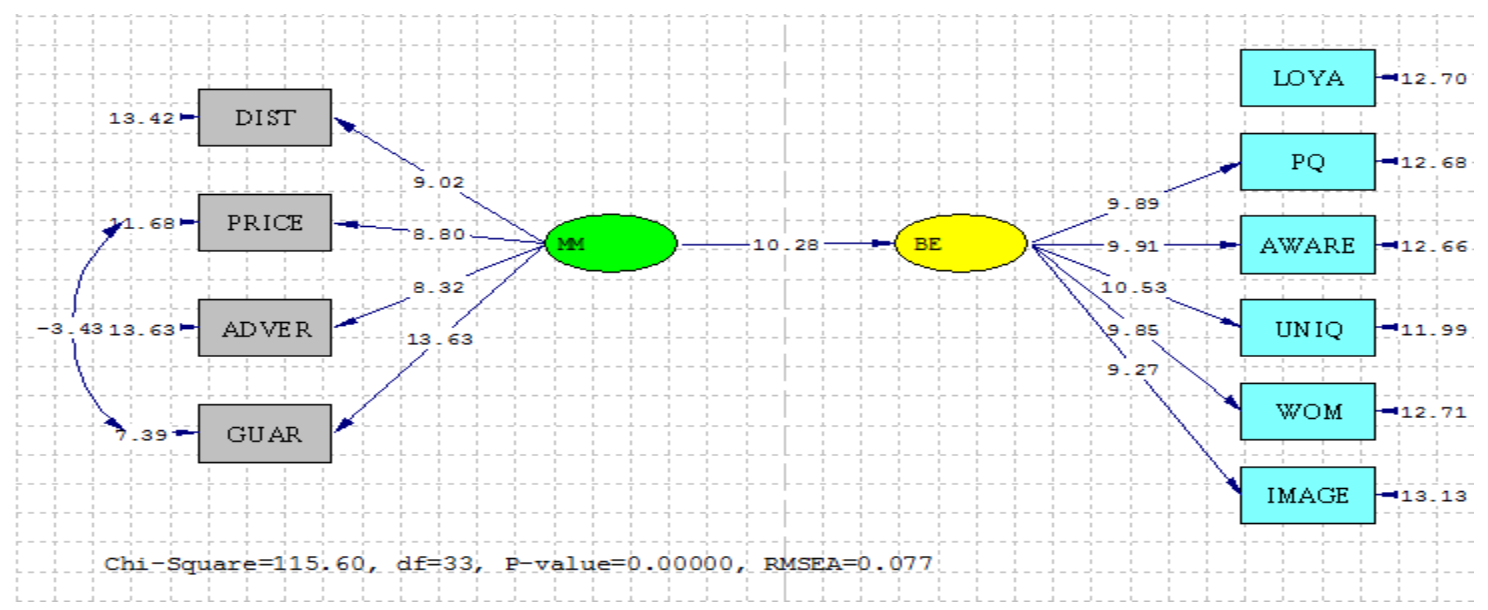

Fig. 2. Standard structural modeling framework

As we can observe from the statistical observations are $\chi^{2}=115.60$ with p-value of 0.0000 , which are meaningful when the significance level is 0.05 .

1. There is a positive and meaningful relationship between marketing mix efforts and brand equity. In other words, more advertisements could help better market exposure, which means customers will have more awareness on market characteristics. Customers evaluate product conditions based on its pricing policy. Better guarantee and distribution policy could help more penetration into market. Therefore, mixed efforts of all these components better influence marking the products.

2. Among all mixed efforts, guarantee influences more on brand equity, which means consumers care more on product services than other features.

3. Among different characteristics of brand equity, product exclusiveness plays an important role. In other words, people are interested in having exclusive product, which is different from others. In fact, they believe they could represent their personality using the product they choose. 


\section{Conclusion}

In this paper, we have presented an empirical study to study the effects of various marketing efforts on brand equity in mobile industry. We distributed a questionnaire consists of 26 questions including loyalty, quality perception, awareness, exclusiveness, word of mouth advertisement, brand name image, advertisement, price, distribution and guarantee. A sample 428 people have been chosen in a city of Tehran/Iran and they were invited to fill in questionnaires on Likert based. The results indicated that there was a positive and meaningful relationship between marketing mix efforts and brand equity. In other words, more advertisements could help better market exposure, which means customers will have more awareness on market characteristics. Among all mixed efforts, guarantee influences more on brand equity, which means consumers care more on product services than other features. Finally, among different characteristics of brand equity, product exclusiveness plays an important role.

\section{References}

Baldauf, A., Cravens, K. S., Diamantopoulos, A., Zeugner-Roth, K. P. (2009). The Impact of Product-Country Image and Marketing Efforts on Retailer-Perceived Brand Equity: An Empirical Analysis. Journal of Retailing, 85, 437-452.

Bandyopadhyay, S., \& Martell, M. (2007). Does attitudinal loyalty influence behavioral loyalty? A theoretical and empirical study. Journal of Retailing and Consumer Services, 14(1), 35-44.

Bendixen, M., Lalala, A., Bukasa., A., \& Russell, A. (2004). Brand equity in the business-to-business market. Industrial Marketing Management, 33, 371- 380.

Boo, S., Busser, J., \& Baloglu, S. (2009). A model of customer-based brand equity and its application to multiple destinations. Tourism Management ,30,219-231.

Burmann, C., Jost-Benz, \& M., Riley, N. (2009). Towards an identity-based brand equity model. Journal of Business Research, 62(3), 390-397.

Cronbach, L. J. (1951). Coefficient alpha and the internal structure of tests. Psychometrika, 16(3), 297-334.

Homburg, C., Klarmann, M. , \& Schmitt, J. (2010). Brand awareness in business markets: When is it related to firm performance?. International Journal of Research in Marketing, 27,201-212 .

Huang, R., \& Sarigöllü, E. (2011). How brand awareness relates to market outcome, brand equity, and the marketing mix. Journal of Business Research, 65(1), 92-99.

Joon-Wuk Kwun, D., Oh, H. (2007). Consumers' evaluation of brand portfolios. Hospitality Management ,26, 81-97.

Kim, K.H., Kim, K.S., Kimc, D.Y., Kimd, J.H., \& Kange, S.H. (2008). Brand equity in hospital marketing. Journal of Business Research, 61, 75-82.

Kohli, C.S., Harich, K.R., \& Leuthesser, L. (2005). Creating brand identity: a study of evaluation of new brand names. Journal of Business Research, 58, 1506- 1515.

Kim, J.H., \& Hyun, J. Y. (2011). A model to investigate the influence of marketing-mix efforts and corporate image on brand equity in the IT software sector. Industrial Marketing Management, 40, 424-438.

Lee, J.S., Back, K.J. (2008). Attendee-based brand equity. Tourism Management, 29, 331-344.

Likert, R. (1932). A Technique for the Measurement of Attitudes. Archives of Psychology, 140, 1-55.

Netemeyer, R.G., Krishnan, B., Pullig, C., Wang, G., Yagci, M., Dean, D., Ricks, J., Wirth, F. (2004). Developing and validating measures of facets of customer-based brand equity. Journal of Business Research, 57, 209- 224.

Pappu, R., Quester, P. (2006). A consumer-based method for retailer equity measurement: Results of an empirical study. Journal of Retailing and Consumer Services ,13, 317-329.

Sweeney, J., \& Swait, J. (2008). The effects of brand credibility on customer loyalty. Journal of Retailing and Consumer Services, 15, 179-193.

Yoo, B., \& Donthu, N. (2001). Developing and validating a multidimensional consumer-based brand equity scale. Journal of Business Research, 52, 1-14. 